\title{
Ethnologies
}

\section{Gnawa Confusion: The Fusion of Algeria's Favorite French Band}

\section{Andrew Mark}

Volume 33, numéro 2, 2011

URI : https://id.erudit.org/iderudit/1015031ar

DOI : https://doi.org/10.7202/1015031ar

Aller au sommaire du numéro

Éditeur(s)

Association Canadienne d'Ethnologie et de Folklore

ISSN

1481-5974 (imprimé)

1708-0401 (numérique)

Découvrir la revue

\section{Citer cette note}

Mark, A. (2011). Gnawa Confusion: The Fusion of Algeria's Favorite French Band. Ethnologies, 33(2), 205-229. https://doi.org/10.7202/1015031ar
Résumé de l'article

Gnawa Diffusion est un groupe musical à succès de première et de seconde génération d'immigrants d'Afrique du Nord, qui a atteint une importante renommée en Afrique du Nord, au Moyen-Orient et en Europe au cours des deux dernières décennies. Ses membres sont établis en France, mais d'origine Algérienne. Leur message politisé et égalitaire a atteint le monde entier. L'habileté des musiciens, leurs instrumentations, leurs goûts et le message qu'ils envoient à la jeunesse ont porté leur musique sur la scène mondiale. Dans son travail, Gnawa Diffusion soulève une panoplie de questions politiques et cherche à représenter son public. Sa popularité a atteint des sommets au plus fort de la guerre civile algérienne. En analysant l'origine du nom du groupe, ce document retrace les événements et les cultures qui ont influencé Gnawa Diffusion, en explorant l'histoire des Gnaoua, l'histoire de l'Algérie, les relations entre la France et l'Afrique du Nord et la musique contemporaine française. Les questions de l'identité culturelle et de la représentation sont étroitement superposées aux intentions du groupe et au processus de production artistique. Parce que Gnawa Diffusion a été pensé et conçu par Amazigh Kateb Yassine, et parce que ce dernier a été reconnu comme le porte-parole et le principal auteur de Gnawa Diffusion, sa vie et ses mots accompagnent l'analyse de ce journal. L'étude des conséquences de la traite négrière d'Afrique du Nord, de la propagation de l'islam, de la colonisation de l'Afrique du Nord et de l'immigration algérienne en France nous permet de comprendre comment Gnawa Diffusion a su créer la nouvelle musique d'une génération qui cherche à surmonter les divisions héritées culturellement. Dans ce cas-ci, la musique défie les notions communes d'authenticité, ce qui transparaît dans les performances du groupe.
Ce document est protégé par la loi sur le droit d'auteur. L’utilisation des services d'Érudit (y compris la reproduction) est assujettie à sa politique d'utilisation que vous pouvez consulter en ligne.

https://apropos.erudit.org/fr/usagers/politique-dutilisation/ 


\section{Gnawa Confusion: The Fusion of Algeria's FAVORITE FRENCH BAND}

Andrew Mark

York University

\section{Introduction}

In 1993 the band, Gnawa Diffusion, formed and led by Amazigh Kateb Yacine, released its first album, Légitime Différence (Gnawa Diffusion 1993). The band's most recent album, Fucking Cowboys, was released fourteen years later in $2007^{1}$ (Gnawa Diffusion 2007). This summer, 2012, following the wave of the Arab Spring (Gouri 2012), the band reunited for a twentieth-year reunion tour. The scope and impact of this band on world, Middle-Eastern, African, French, European and popular music is difficult to measure, particularly for an American Anglophone like me. The group's increasing popularity and musical excellence paralleled rising global interest in and knowledge of the music of the Gnawa people from North Africa. To dig up and lay bare the roots of Gnawa Diffusion and their music is to uncover a complex web and confluence of personal, societal, and international influence, where narratives of slavery, identity, possession, migration, fame, conquest, nationality, and frustration clash, combine, and splinter. As a result of a series of "interpretive moves" (Mientjes 1990: 37; Feld 1984) and for narrative glue, my inquiry problematizes the band's name. What can we learn about cultural signification from this band of light-skinned Northern Algerians living in France who appear to make an appropriative claim on a historically Black Moroccan religious musical order, the Gnawa? As this task is nuanced with delicate and fragile politics and musics, this paper represents only a surface inquiry into the multiple meanings available within Gnawa Diffusion through speculative media analysis and research, and without fieldwork.

1. On the day before this paper was first submitted, I discovered the band reunited for a 2012 twentieth-year reunion summer tour to promote a new album that has yet to be released. 
In this paper I describe some of the histories that led to the creation of Gnawa Diffusion. These histories include those of the Gnawa people, the indigenous Berbers of North Africa, the nations of Algeria and France, and Algerians who have immigrated to France. By weaving in the band's personal histories into this reconstruction, and by engaging issues of authenticity and identity, I situate the use of Gnawa music by Gnawa Diffusion relative to the band's other influences. As in my work concerning the blending of Zimbabwean mbira dzaVadzimu and hip hop music (Mark 2011), I conclude by arguing that Gnawa Diffusion's use of Gnawa music is not ignorantly appropriative, but instead, performs the band's own kind of authenticity, one that transcends museum standards of representation and achieves something more heterogeneous. The eight-piece band, with a popular musical base instrumentation of drums, vocals, bass, guitar, keyboards, and percussion, chose to add instruments and a repertoire from Gnawa traditions to signify new meanings that transcend the sum of their parts. Why? And what does their music signify? Because Gnawa Diffusion was envisioned, organized, and led by Amazigh Kateb Yacine, and because the band and media recognized him as the spokesperson and principal author for Gnawa Diffusion, Yacine's life story and words from interviews accompany my arguments and analysis.

\section{Indigeneity}

The Maghreb in Arabic can mean "west" and "place of sunset" relative to the expansion of Islam from the $7^{\text {th }}$ century onwards, and also denotes that area stretching across North Africa from western Egypt to Mauritania. Maghrebi is the dialect of Arabic that is spoken in the Maghreb and also refers to the Maghrebi people, generally understood to be anyone living in the Maghreb, though the term is associated with an Arab worldview. The indigenous people of North Africa who lived in the Maghreb long before the birth of Islam are historically known as the Berbers, but now some self-identify as Imazighen. Where I use the term "Berber," I do not mean the dated French conception of a non-Arab North African race of Europeans (Hoffman 2008: 13-22). In Algeria, between one quarter and one third of the population is Imazighen (BBC 2012). In terms of ethnicity, Hoffman reports that in academia, it is generally accepted 
that the indigenous people of Northern Africa, popularly known as the Berbers, were the Imazighen (2008) which means "Noble and Free Men" in Tamazight (Kazak 1996), the language of the Imazighen. Today, the term Imazighen also signifies activists and militants who believe in a unified Amazigh nation in Northern and Western Africa, the Tamazha, where people are free to speak Tamazight.

For Gnawa Diffusion, the struggle of the Imazighen for selfdetermination was an important and personal issue. The band's efforts focused on a dialog of self-discovery in the Maghreb, and Yacine took important inspiration from his Imazighen heritage. ${ }^{2}$ The refusal of the Imazighen to submit to cultural erasure is a powerful tale of resistance that spans centuries (ibid. 2008: 1-45). Whereas Yacine wrestles with appropriative issues regarding his use of Gnawa music, the French language, hip hop, and many other layers of identity, the Imazighen struggle is an important aspect of his identity that he proudly wears without equivocation of justification (Smati 1999). Bitter battles for Imazighen freedom are coded in the translation of Yacine's first name, Amazigh, which means "free man" in Tamazight, the linguistic group of Imazighen dialects (Hoffman 2008: 13). Today across the Maghreb, the "Amazigh movement" seeks to empower Imazighen. For Gnawa Diffusion's audiences, Amazigh Kateb Yacine's proper name doubly signifies the band's relationship to indigenous Imazighen sovereignty because Amazigh's father was Yacine Kateb, a famous Algerian activist writer.

\section{Colonization of North Africa}

Permanent expansion of Islam into Algeria and Morocco began in the $11^{\text {th }}$ century with the Beni Hilal Bedouin invaders from Egypt, bringing extensive Arabization into urban areas (Kazak 1996). Since this time Imazighen have been forced, encouraged, and enticed to do away with local and rural languages and culture, and to assimilate to Arab and European ways. These pressures correspond to increasing rates of urbanization and rural dispossession.

2. My assertions about Amazigh Kateb Yacine's opinions are based on his own assertions in interviews with various magazines, newspapers, and journals, not from any personal communications. 
Significant parts of the Maghreb were ruled by the Ottoman Empire from the $16^{\text {th }}$ century until the French seized Algiers, the capital of Algeria, in 1830. The French controlled the majority of Algeria by 1848 (Kazak 1996). As rural sites of autonomous authority, community, and resistance, the French particularly sought out Imazighen communities to dismantle and colonize. However, there were several Algerian movements of revolt against French rule, and the Imazighen led the cause for national solidarity time and time again (ibid. 1996). When Algeria finally gained independence in 1960, ethnic tensions between formerly allied Arabs and Imazighen rose again. Since independence, Imazighen have held demonstrations for rights within Algeria, and many have been violently repressed. In 1992 an election was canceled by the original 1960 revolutionary government when an Islamist party appeared to be winning. Civil war ensued. The intensity of the war climaxed at the same time as a broader coalition of Imazighen across the Maghreb successfully drew international attention to the oppression of their indigenous heritage. In 2001 the Algerian government agreed to recognize Imazighen language, culture, and contributions (BBC 2012). The Amazigh movement captured the attention of academics, historians, and politicians, and because of this, the place of Imazighen society in North Africa seems more promising today. Yacine, the leader of Gnawa Diffusion, returned to his home in Algiers with the band in May 2001 at the peak of the demonstrations which saw tens of thousands of Imazighen in the streets marching in defense of their rights. The result of the visit was an exceptional concert of homecoming, which became the material of the band's CD, Live-DZ (Gnawa Diffusion 2001).

\section{The Gnawa}

During and after the Byzantine and Ottoman Empires, conquest, enslavement, and forced migration brought and circulated slaves between the European and Arab worlds. People from West Africa and as far east as Sudan, were enslaved by Arabs. Sometimes people from more Northern areas were also taken. While the term Gnawa is derived from several possible linguistic origins and slaving cultures, all variants translate it to refer to "Black people," and it is used as a means of distinguishing Gnawa from lighter skinned African 
Northerners who are generally Imazighen and/or Arab (El Hamel $2008,243)$. In the $15^{\text {th }}$ century the term Gnawa, or Gnaoua in French, became associated with a particular religious order in Morocco that included slave membership.

The experience of Blacks in Northern Africa contrasts with the history of the Imazighen. Historically Black people were enslaved by Arab states to create militias to control the Imazighen. In Morocco "under Mulay Ismail (1672-1727), more than one hundred fifty thousand soldiers of Sudanese origin were recruited to control the Berbers" (Waugh 2005: 109). The experiences and culture of Black slaves in North Africa directly inform Gnawa Diffusion's music, and, obviously, their choice of band name and their identity as a group, but this appropriation is complex.

During this movement of people, Black slaves assimilated new languages, religions, and cultures that were fused with indigenous African traditions and spirituality. Gradually, over a time spanning from the birth of Islam in the $7^{\text {th }}$ century to the $20^{\text {th }}$ century, slaves formed mystic Islamic orders that emphasized spiritual and physical healing through music involving communion with spirits, possession, divination, and all-night enactment of semi-canonized ritual. From Yacine's interviews, we know he traveled to Morocco to seek out musical training, and that one of the band members actually has Moroccan Gnawa roots (Marsaud 2004).

In cosmopolitan contexts (Turino 2000), the Gnawa are framed as a religious group with a compelling musical tradition based in Morocco, and race is not always an explicit aspect of this understanding. However, one can find "Moroccan Gnawa music" in a modern music store without trouble, and it is not uncommon to read something like this in the liner notes: "When I first came to Morocco, the Gnawa were almost uniformly black, and many still spoke their native tongue, Bambara. Today most of them are considerably lighter in colour, and have replaced Bambara with Darija Arabic" (Bowles 1990). Race is an important aspect of Gnawa identity and memory (Kapchan 2007); however, Bowles is correct in his assertion that people of many races identify as Gnawa. In the Garland Encyclopedia of Music, the Gnawa are described as "negroid Africans" in North Africa (Wendt 1997). Within Morocco, Gnawa understand themselves 
to be loosely grouped into two religious orders of Gnawa, and only possibly use "Gnawa" as a term for racial signification. While the term Gnawa may be understood across North Africa as "Black person," and thus, "Gnawa music" can mean "Black music," the Gnawa in the cosmopolitan Moroccan sense are only one spiritual and musical group among many across the Maghreb who follow traditions that are more accurately kept under the umbrella title, the Sidi Bilal, the Brotherhood of Bilal (Addoun 2009). The Moroccan Gnawa are like a sect of the Magrebi Sidi Bilal. These subtle distinctions in meaning are important when considering Gnawa Diffusion's name, how they understand their representation of a music with an important racialized history, and the manner in which the band members refer to the band and each other as "Gnawa" though they are all lightskinned Northerners from Algeria with, from what I can gather, few direct ties to Morocco (Gnawa Diffusion 1997).

The Sidi Bilal are found in many places along slave trade routes (Jankowsky 2004; 2007) like "the Stambouli in Tunisia, the Sambani in Libya, the Bilali in Algeria, the Zar cult in Sudan and Bori among the Hausa of Northern Nigeria and Niger" (El Hamel 2008: 243-244). All of these orders of the Sidi Bilal bear commonalities with forms of Sufism (Waugh 2005), yet differ significantly in that they are connected specifically to slave histories. ${ }^{3}$

Tragically, while Islam professed to eradicate slavery through a system of "optional" indentured servitude, it also thrived on the trade, as did the Christian world. The Gnawa are steeped in an ancestry of possession and ownership (Kapchan 2007: 34, 54), and their musical heritage is, among many possible explanations, an expression of individual and group struggle for agency and solidarity, on earth, in the heavens, and in the spirit world. One interpretation of the historical function of Gnawa ritual is to interpret their practices as methods for mitigating a lack of self-determination and possession by others (worldly and otherwise) in order to find sanity, healing,

3. For the purposes of this paper and with consideration to readily available English sources and translations, I will continue to use the term "Gnawa" and focus on Moroccan Gnawa instead of the Sidi Bilal, though I hope my reader can now position the Gnawa as Moroccan specifically, a group within a larger whole that has been described by a body of literature mainly in French (Paques 2005; Claisse 2003). 
endurance, peace, and a framework for happiness. This history contains a grim hypocrisy because of the role that Gnawa understand Black people to have had in the birth of Islam.

Oral accounts of the origins of Gnawa practices are shrouded in conjecture, religious myth, music, and a sense of painful injustice. Many Gnawa trace their ancestry back to a single person named Bilal. For the Sidi Bilal, Bilal was the first Black Muslim, and he was for a time Muhammad the prophet's adopted son (Waugh 2005: 106). He was a manumitted slave, and one of Islam's first converts. Importantly for the Gnawa and their emphasis on musical and spiritual healing, Bilal was the first muezzin of the original ummah (ibid. 2005: 106); he was the first person to call Muslims to prayer. This makes Bilal a kind of patron saint for Black Muslims (ibid. 2005: 106). Interestingly, Bilal is also associated with shoes. One of the signature Gnawa instruments (and that of other sects of the Sidi Bilal) is the krakabas which are a kind of metal castanet that in one story are said to be made from the soles of Bilal's shoes. Bilal alone is able to lead on the path into paradise wearing his shoes because of his importance to Islam and the prophet. It is the sounds of Bilal's feet on the floor of heaven that lead the Gnawa into a spiritual state (ibid. 2005: 106), and Bilal's feet heavily feature in Gnawa Diffusion's music. To the dismay of those seeking to erase Bilal's importance to the Prophet, aspects of this story are recorded as fact in Islamic history (ibid. 2005: 109).

The instruments, repertoire, and rituals of the Sidi Bilal traditions are very similar to one another, and they are difficult to distinguish for a neophyte like me. In an interview Yacine was asked the question: "Is there a real difference between the Algerian and Moroccan Gnawa?" He replied:

Absolutely. The Moroccan Gnawa have not been restricted by the authorities as they have in Algeria. The Moroccan Gnawa have always conserved a status and the right to officiate. Their Gnawi title is stated on their identity cards. The Monarchy has protected them. In Algeria, the bureaucratic and homogenizing policy of the Boumedien period [when cheap labor was enticed north after Algerian independence] pushed the Gnawa into joining the cohort of sterile civil servants, becoming bailiffs or school caretakers, for example. They no longer needed to travel and officiate to meet their needs and survive as they did in Morocco. Some did not accept this new way of life and continued practicing their art, 
but it was practically hidden away in private or family events. People continued to have them come as far as Algiers to see them perform. (Yacine 2009).

The thrust of this quote, as others (Mutasa 2010), illustrates Yacine's understanding of the need to restore the place of African identity within Algeria, and indeed, Black identity. An important aspect of the philosophical foundations of the Gnawa, and by extension, the band, is their emphasis on spiritual battle. The idea of jihad, the Gnawa insist, is a spiritual battle that was wrongly turned over to the state long ago. The Gnawa provide a vehicle for engaging with one's jinn, the spirits that inhabit our bodies and realities. One's spirituality and commitment to Islam is measured by managing these encounters. Here spirituality is the depth of one's resolve to find peace through jihad. For the Gnawa, "the Quranic material on jinn has not been accorded its proper place in the Islamic theological system" (Waugh 2005: 112).

Deborah Kapchan's work in Traveling Spirit Masters: Moroccan Gnawa Trance in the Global Marketplace demonstrates that authenticities of performance, representation, and Gnawa identity are contested by heterogeneous groups of Gnawa (Kapchan 2007: 22). Morocco hosts an enormous annual festival of Gnawa music with a spectrum of both sacred and secular performers (Water 2004, Festival Gnaoua 2012). However, healing by engaging inner struggles, brought on by spirits and beings in our world, is fundamental to most representations of Gnawa in folkloric, sacred, and secular contexts. This musical healing through internal dialog is what Gnawa Diffusion replicates in its representations of Gnawa culture.

\section{The songs of Gnawi}

North African cities became the homes of the Sidi Bilal in places like Tangier and Essaouira on the northern and western coasts of Morocco because this is where the trade routes ended from east to west, and from south to north. This is also where Berber culture, Andalucía, Islam, and Africa collided. The dances, instruments and their organology, the rituals, songs, and the singing styles of modern Moroccan entertainment demonstrate aspects of musical 
preservation, recombination, and innovation. Musicians maintain traditions that reflect heterogeneous possibilities.

In secular performance and in sacred ritual, the Sidi Bilal are known for using three instruments in particular (Langlois 1998), all of which are used by Gnawa Diffusion. The guimbri, or sintir (known by many other names and clearly related to the West African ngoni), has a wood rectangular box or oblong bowl as its resonant body that is covered on the face side with animal skin. The strings are plucked with a technique that is similar to "slapping and popping" on a bass guitar or doing a "thumb-diddy" on a banjo in a highly syncopated fashion. Sometimes metal buzzers are attached to the guimbri to enhance the sound. The guimbri is the instrument of the mallem, the master of ceremonies who generally leads a troupe of musicians through a procession of rituals involving specific foods, incense, practices, colours, saints, and jinn. Ceremonial participants will perform transformations and acrobatics, and will dance and 'trance' (Kapchan 2007: 1-4). A typical seated ensemble includes one guimbri and several krakabas players while everyone sings in call and response patterns, sometimes with clapping. There are also the tbel, which are large double-headed drums that are played with sticks, alone, or in pairs or more, and have their own repertoire which is generally more secular and accompanied by dancing and acrobatics (Langlois 1998; Schuyler 2009).

Gnawa Diffusion's albums include songs that exclusively use these instruments and call and response vocals. They sound like high fidelity studio deliveries of traditional songs. A good example of this is the title track of their first full-length album, Algeria (Gnawa Diffusion 1997). Other albums feature interludes with Gnawa-sounding grooves, as if borrowed directly from a ceremony, like "Ya Laymi" on their album Souk System (Gnawa Diffusion 2004). Still other songs include fusions that use a drum kit player and bass guitarist to simulate the sounds of the krakabas and guimbri like "Sabrina/Gaz Naturel" from their Bab El Oued Kingston album (Gnawa Diffusion 1999). For entrance and exit on their Live DZ album (Gnawa Diffusion 2001), the band marches in procession onto the stage with tbel and krakabas.

In describing the music, Yacine makes an important and subtle point, explaining that when the band creates songs, they try to 
avoid altering the traditional use of Gnawa instruments or songs to suit other instruments, goals, or musics, but rather, to find grooves, melodies, and rhythms that naturally fit together. In this case, a traditional guimbri pattern would have been grafted, not mixed, with a modern hip-hop beat. In other words, the guimbri was never used to simulate a bass guitar line by the band (Zergane 2006). We can speculate that the band's audiences may not have appreciated this nuance, but after careful listening, one can find reason to praise the earnest effort with which the band sought to treat Gnawa music with a kind of reverence.

Gnawa music is wonderfully hypnotic, and if a listener ever "falls" (Kapchan 2007: 54) and begins to trance, then he or she is understood to be possessed by jinn and/or saints. Possession can be a life-long boon or burden

However, recognizing possession may allow a person to identify a spirit, and to placate and work with it. For Yacine, his discovery and exposure to music similar to the Gnawa's was the epiphany and the spark for Gnawa Diffusion.

In 1982 Yacine traveled with his mother to Timimoun in southern Algeria:

I first discovered this African Algeria I had been robbed of in the North in Adrar [...]. It was a huge shock in terms of identity, music, and language. I discovered sounds that were practically foreign as they had been so deeply hidden in my and my ancestors' memory. It was in this wonderful region that I experienced my first poetic and musical emotions. During the nighttime gatherings, everybody more or less played an instrument, respecting a certain volume. Even the participants who weren't musicians clapped their hands gently, trying to hum along with the chorus to participate in the elaboration of something very gentle, very melodic. I was charmed when I discovered these Algerian Gnawa songs (Yacine 2009).

To this day, I remember dancing like I was crazy until the late hours of the night. I suffered what can be called love, if you like, because I discovered the African face in my personality. Algerian schools, even today, do not mention that Algeria deeply belongs to the brown continent. Even the elitist intelligentsia have become divided into two. First, those who fiercely defend the Western and imperialist Francophone, and second, the ignorant defenders of a pure Arab and Islamic Algeria. In southern Algeria, no 
massacres happened during the past dark years. The people live as if they are in another country; they having nothing to do with the dirty war imposed on the people living in the northern part of the country. The explanation closest to the truth is that the south lives its identity with all its extensions, while the residents of the $[\mathrm{N}]$ orth are engulfed in dirty wars created by the identity merchants. (Yacine 2003)

In Timimoun we might speculate that Yacine encountered the Algerian Bilali brotherhood of the Sidi Bilal, who were perhaps Black, and self-identified as "Gnawa," though literature associates this term with Moroccans. It is also possible these quotes betray a lack of attention to detail, or ignorance on Yacine's part. His first quote clearly includes a transformative experience, and I suspect this is one of the explanations for the band's name. In the second quote Yacine also displays his understanding of the disconnect between southern and northern Algeria, indicating his desire to reconcile this divide (in the context of the interview) through his music.

\section{Africans in France}

"The third world's God is a big black Gnawi. Ah-he's a strongah drummah, he plays guimbri, guimbri, guimbri-i-i..." (Gnawa Diffusion 1997)

There is a common feeling of new opportunity and post-colonial enmity among some Africans who find themselves in their European colonial homelands (Mark 2010). It is a mixed feeling that, at best, can create ambiguous realities. Africans in Europe can receive a wide variety of stigmata and prejudice based on many stereotypes, cultural, religious, sexual, racial, and perhaps most importantly for immigrants, they encounter significant class-based bigotry (Sayad 2004). Some cannot afford to return home and find themselves working in conditions that undermine their self-worth, their talents, and their qualifications (Thomas 2007: 115-54). Many immigrants are pressured to funnel money home, while lying to their families about what they are doing in the industrialized world, how happy they are and where their money is coming from. Muslim immigrants in particular face discrimination widely within Europe, and North Africans find themselves frustrated and feared (Beriss 2004: 43). As 
I will discuss later, by focusing on rap music in France, pretentions and attention to cultural and musical purity regarding the control and erasure of Islamic influence within the state are no less present in France than they are in Buchanan's Bulgaria where state intervention sought to actively eliminate Arab influence (Buchanan 2006). Within an Algerian context, Gnawa Diffusion may have oriented itself towards internal struggles between Black, Imazighen, and Arabs, but within France, Gnawa Diffusion understood themselves as a band of immigrant Africans with Islamic cultural influences fighting against discrimination. The band signified its intended audience by using not only instruments and musics, but by mixing Tamazigh, Arabic, English, and French. I cannot confirm the degree to which the band members experienced racism, but their music spoke to such experiences.

During the post World War II economic boom and before the 1970s oil crisis in France, many Algerians were encouraged to immigrate to France as laborers and establish firm roots (Silverstein 2004: 23-25). Yacine arrived in France at age sixteen in 1988 with only his mother and began to form Gnawa Diffusion immediately after his father's death a year later (Smati 1999). Yacine came to feel his life story as an Algerian in France was analogous to Gnawa slaves, plucked from their ancestral homes, because his residence in France became necessary as he was unable to return to Algeria for almost ten years for fear of military conscription. While the band solidified in the 1990s, and while civil war raged in Algeria, Yacine came to understand an Algerian African immigrant's life (Smati 1999; Silverstein 2004: 213-15).

In Algeria Yacine experienced the oppression of Black Africans from an outsider's perspective, but he could relate to their minority status to some degree as an Imazighen himself. In France where multiculturalism is often synonymous with shades of whiteness, as Algerians and Africans, Yacine and the band likely experienced systematic police profiling, racism, Islamophobia, and varying degrees of economic hopelessness in French banlieues, cités, or ghettos. Packed in with immigrants from ex-colonies around the world and poor French people, Yacine formed his own Algeria in exile while watching his real homeland tear itself apart between various Islamic and Imazighen fundamentalist, nationalist, moderate, and separatist 
movements. Gnawa songs are often those of exile and longing (Baldassare 2005: 82), and so were Yacine's. In these experiences, Yacine saw himself as entirely African, not only a light-skinned Algerian (Smati 1999).

French colonization generally repressed Algerian culture as a whole, undermining functioning legal, economic, and educational system. In 1954 the National Liberation Front in Algeria brought together Algerian interest groups to launch a guerilla war of independence that was construed as a terrorist movement by colonial France. Sensing this history of invasion, torture, and war crimes repeating itself in recent times in the Middle East, Gnawa Diffusion featured U.S. politics in their music after 2003, offering idiomatic American banjo licks while denouncing George W. Bush (Gnawa Diffusion 2007). During the Algerian struggle for independence, Yacine's father, Kateb Yacine gained an international reputation as an Algerian nationalist writer, poet, and playwright. After independence, his work turned to colonial legacy and the internal oppression of Imazighen in Algeria (Corcoran 2007: 48-51). Amazigh Kateb Yacine grew up in the theatre, performing his father's works (Saidani 2003). It is difficult to underestimate the kind of radical impact Kateb must have had on Amazigh.

\section{If All Africans are Black, and we are all Africans, then...are we all just Africans?}

As a band that did not include any Black members, the following excerpt from an interview with Yacine highlights Gnawa Diffusion's understanding of their relationship with Gnawa music, Black identity, and with Africa:

Chehat: Does the Arabs' slave trading past hinder the improvement of North-South relations? Black Africans are still profoundly suspicious of Arabs...

Yacine: I think that the only way out of this problem is to open our arms to others, to those who were dominated or humiliated by our ancestors. We need to offer an outstretched hand, an open heart and above all a lot of humility. We need to make them realize that they too have strongly marked our culture. What can be a greater homage than to see a White person playing the guembri, 
which is the emblematic musical instrument of the Black man he despised and martyrized yesterday! This kind of homage does not resolve much, of course. It is also, above all, necessary that the descendants of the slave traders that we are have the courage and the strength to recognize that hurtful past. This self-criticism has unfortunately not yet started. (Chehat and Yacine 1998)

Gnawa Diffusion was founded in the French cités. In the cités there is a shared colonial experience among immigrants from all over the greater French Empire, from the Caribbean to Cambodia (Berris 2004: 63-81; Thomas 2007: 1-40). Gnawa Diffusion's mix of sounds relied heavily on Black musics of the Caribbean. The band identified with Jamaican Rastafari musical aesthetics and with aspects of Rastafari messages of liberation and struggle. They subscribed to and promoted the use of marijuana. The Gnawa are also known for their use of marijuana in ceremonies, practice, and daily life (Waugh 2005: 179), though ceremonial participants appear to generally refrain (Kapchan 2007: 127-129). Similarly, Rastafari and Gnawa both engage aspects of control, possession, and agency in lived histories of slavery by performing resistance music.

Veronique Helenon explains why issues of Black and African identity in French hip hop are transformed into understandings that are unique to the cités and deviate from the relationships between Black identity and hip hop in North America:

Over time, many groups have come up with a meaning of Black that is not so much about color of skin as it is about asserting one's origins and heritage in a country where multiculturalism is in fact largely synonymous with Whiteness. From this perspective, Africa is redefined according to norms that refute its traditional definition. For instance, North Africans are traditionally considered to be closer to the Middle East than the rest of the African continent, but in the French context, many rappers have shaped connections that go beyond these classifications. Thus, although Maghrebians are generally not regarded as and do not consider themselves as Black, they can be included in a common African identity which does not necessarily have to do with the color of skin. (Helenon 2006: 161) 
Gnawa Diffusion is a group of Maghrebis. They distinguish themselves from Eastern Arabs and yet also acknowledge their Arab heritage:

Chehat: The Maghreb is physically part of Africa but in reality seems to turn its back on the rest of the continent. Interest in the continent is limited. Africa is absent in both the media and culturally speaking. What do you think can change this situation?

Yacine: I think the Gulf War opened a lot of people's eyes regarding unity in the Arab world. The Arabo-Islamic Maghrebi identity promoted by the politicians is little more than an exterior identity in reality. Furthermore, this veneer which the hardliners would like to see imposed in our countrie, is not necessarily condoned nor conceded by the Middle Easterners themselves. In most Middle Eastern countries, the Maghrebi are considered to be Arab-speaking Africans. They are effectively seen as "minor" Arabs. I should know, as part of my family lives in Syria and in the Lebanon. The Maghreb is not at all geographically linked to the Arab peninsula. Its roots lie in the South: the Maghrebi should, and will eventually, turn their attention to Senegal, Mali or Niger, especially as Africa's turn has come on the world stage. Africa is back on the agenda. There are signs of its comeback everywhere, both in the Anglo-Saxon and Latin countries.

Chehat: Do you think that the Maghrebi populations will become progressively absorbed into the Middle Eastern sphere culturally speaking, as a result of the Arabization policies imposed with more or less vigor by the public authorities?

Yacine: Even though the people in power desperately continue to deny the Maghreb's Africanness, that doesn't make it any less real. It doesn't matter if Africanness isn't taught at school and doesn't feature in the school books as it is present in everyday life, from cooking to dance, music and gestures. The public powers can install an institutional, State, official culture. It will struggle alongside the popular cultures that are really rooted in society but will never be able to erase or replace them. Identity cannot be determined by decree. It comes from the very soul of the population, and the soul of the Maghreb is African.

Chehat: The name of your group "Gnawa Diffusion" clearly refers to Algeria and the Maghreb's African aspect....

Yacine: It was a way of setting the records straight and of saying no to the occultation of a vast part of Algeria. Of course the majority of the population lives in the North, but a significant part of this very majority left the South to survive, work, seek comfort and 
well-being. What is more, Gnawa songs and music are similar to the songs and music of the Black Americans: they are songs of suffering, religious protest songs, mystical songs... And that takes us to the very heart of Africa! (Chehat and Yacine 1998)

Thus, as Helenon suggests, these Algerians reaffirmed their African identity through Black musics. What are these philosophical and musical connections to Black Americans? Gnawa Diffusion's music is clearly marked by popular North American stylings.

\section{Hip Hop in France}

Recently inside France, issues of marginalization, poverty, lack of employment, education, and opportunity led to annual riots by populations of first, second, and third generation Africans and North Africans. The most spectacular, frustrated, and tragic riot that brought global attention to French equity and immigration issues was in 2005 (Osumare 2007: 70). Over the course of three months, 2,888 people were arrested from 274 towns that were well dispersed across the nation (Snow, Vliegenthart, and Corrigall-Brown 2007). With foreseeable irony, President Chirac enacted a state of emergency rule of law that was previously used by the French in the Algerian War of Independence (Osumare 2007: 87).

In the last two decades, French hip-hop artists were accused of inciting and fueling these riots. France is considered the largest producer and consumer of hip hop outside of the U.S. (ibid. 2007: 84). Rap is globally known for finding a common thread through culture, class, historical oppression, and youth rebellion (ibid. 2007: 72). In fact, after the riots, two hundred French members of parliament petitioned for legal action against several French rappers (Poggioli 2005). Considering the years and strength of hip hop in France, often published, performed, and promoted by Africans (Schofield 2005; Brown 2008), it is unsurprising to note that rappers like Algerian born Mohammed Bourokba, better known as Hamé from La Rumeur, have been in and out of courts since 2003 for vocalizing just how difficult life is for African immigrants and for forecasting how easily riots could break out (Schofield 2005). "Taken as a whole, the French rap scene is eclectically resistive, reflecting France's former colonial subjects who now 'talk back' to the mother country from 
within its borders" (Osumare 2007: 85). French rap is full of its own traditions of word play. For example, MC Solaar, a rapper originally from Senegal, mixes his home country's rhetorical griot tradition with French verlan (the inverting of French phonemes; for example "police" becomes "licepo," hence, verlan, l'envers, to invert), with the French pop music tradition of puns, plays on words, and suggestive phonetic combinations, and with African American traditions of competitive signifying (ibid. 2007: 85).

Here too in this experience of North African outrage in France, we find Gnawa Diffusion. The following lyrics from their 1997 album Algería with "Bleu Blanc Gyrophare" (Blue White Revolving Light, signifying the police, colours in the French flag, the State, and authority) serve as an example (Gnawa Diffusion 1997):

Bleu blanc gyrophare in a action tous les soirs

Ils vont faire un tour dans les cités dortoirs

Opération coup de poing toujours dans le noir

Ouverture de la chasse aux jeunes et aux trainards

Et s'ya pas de vrais coupables, il y a toujours des zonards

Si tu parles de bavures ils perdent tous la mémoire

\section{REFRAIN :}

Bleu blanc gyrophare

Bleu blanc gyrophare

Bleu blanc gyrophare, danse, danse sur la police...

Blue white police lights in action every night

They will go around the public housing high rises

"Operation Punch" (police surveillance), always at night

Opening the hunt for youths and laggards

If there are no real culprits, there are always zonards

(people from the banlieue, the cités, the "projects")

If you speak of (police) blunders they lose all memory

\section{REFRAIN:}

Blue white flashing light

Blue white flashing light

Blue white flashing light, dance, dance on the police .... 
Given the conservative political backlash against rap in the new millennium, it is hard to believe that at one time in the 1980s, French politicians actually courted rap artists like Afrika Bambaataa (an important early figure in the history of hip hop) and his Universal Zulu Nation project to come to France and help "channel youthful rebellion into the aesthetics of hip-hop's four elements," (Osumare 2007: 85-86). However, in the 1990s priorities changed, and authorities perceived the way in which the French language was mixed with English and Arabic in the banlieues as a threat, contributing to the creation of the Toubon Law of 1994 (which mandated the legal preservation of the French language), and aided the successful prosecution of many rap artists (ibid. 2007: 89). By 2002, politicians like Jean-Marie Le Pen, a National Front candidate for the presidency "denounced rap as a dangerous art which originated in Algiers" (ibid. 2007: 89). At this time, Algeria was just beginning to recover from ten years of bitter civil war which had spilled over into France on several occasions (Silverstein 2004: 129-135).

Below, Osumare delicately explains why hip hop is so meaningful to bands like Gnawa Diffusion who seek to improve the position of Africa in the world:

Wherever the Africanist aesthetic has migrated, it has been relegated to a vernacular, low art status, even as its principles have increasingly become the basis of global popular culture. This ranking in relation to European classicism has given it a culturally marginal status that in some ways hip-hop is correcting, and in other ways it is providing fodder to the historic cultural hierarchy. Herein lies the complexity of hip-hop at this current juncture in the history of the Africanist aesthetic. However, whether a particular international site has historical connections to the Africanist aesthetic or not, hip-hop's revision of the Africanist signifying tradition provides bragging right to any adept emcee, b-boy, or deejay. This often results in the extolling of an emcee's or dancer's point of origin-specific neighborhood, district, housing project, or street corner. This local signifying garners respect and prominence for an artist's community context, whether bound to hip-hop through the marginality of culture or not.

Many global communities are given overdue visibility and recognition based on hip-hop's ability to generate connections of marginality, resulting in a clear understanding of the global-local 
problematic through hip-hop's "beat streets" that create a kind of global hood (Osumare, 2007: 73).

Gnawa Diffusion was based in Grenoble in the Southeast of France. Yacine and most of the members of Gnawa Diffusion are directly from Algeria or are second or third generation French Algerians (Gnawa Diffusion 2009). However, they saw these struggles for authenticity as a part of a much larger system of oppression enacted by people of European ancestry, and their music performed this through another reflection of the African Diaspora, the diffusion of hip hop.

\section{Conclusion: Authenticity is a question, not a quality}

I submit the following to guide our consideration of Gnawa Diffusion's authenticity:

The fact is that performing outside the confines of the [Gnawa] order is a very recent trend; the context has traditionally been an essential element in performance. Those who are masters within their own context perform where they carry out a familiar and well-patterned function. Music of that function cannot be transported to another environment; the memory of its past greatness dictates that because one needs the memory to activate the spiritual realities. Memory is thus the basis of this religious encounter (Waugh 2005: 155).

Gnawa Diffusion as a group is not confused about its representation of Gnawa people, or the Sidi Bilal, but its audiences may have been, and may be. I wrongly assumed for years Gnawa were people from Algeria, and of course, they are, but we cannot guess which layers of meaning the band intended to appropriate when choosing their name, even if we assume the band embraces any or all of the various meanings of the term. We must place some burden of misrepresentation and confusion upon Gnawa Diffusion themselves. It would seem the name "Gnawa Diffusion" was intended to signify African connection through hip hop, through reggae, and through Gnawa music for people who have been uprooted from African homelands to start lives in foreign lands. Yacine sees the group as part of a larger diffusion of Africanness around the world (2010). 
However, the band does not only attempt representation of "Gnawa" diffusion, the African Diaspora, but also highlights the struggle of Muslims to live without prejudice, and promotes the rights of indigenous Amazigh Berber people. Their songs call upon France to witness what has been done to Algeria, and for Algerians to remember whom to hold accountable. The band has a profound sense of respect for the sacred. For example, Yacine will not be pressured to translate one word of the 300-year-old song "Shara Allah" which belongs to a distinguished musical genre in Algeria, known as Al Shabi (Saidani 2003). Also, towards the end of the band's career, they have featured more Chaabi songs and instruments that are the popular and folkloric musics of northern Algeria (Gnawa Diffusion 2004; 2007). These musics are not associated with a Black identity. Yacine states that the lyrics for most songs were "Street Arabic," a mix of many languages. He defends this language against pressures to be either French or Arabic (Saidani 2003). And so the band's authenticity is nuanced and complex.

There are too many layers to this story to ascribe Waugh's authenticity above to the self-proclaimed Gnawi of Gnawa Diffusion, but I argue that in this case authenticity is performed, and based on the fact that performance is conferred or denied (Mark 2010). Authenticity is also based on a set of given subjective criteria, and I can see why others might reject my conclusions. The band borrows musics from all around the world because they are surrounded by them. Their experience of these musics is embodied and lived (Wahab 2005: 47), not abstracted and mediated (Taylor 2007: 185-208). One could argue that the band is simply from post-colonial France, where people have been appropriated from all over. This too would be subjective. The band's performative context was and is one of mediation through CDs, iPods, YouTube, bootleg tapes, MP3s, and the radio, as well as live pop music presentations for huge audiences. The band is clearly a master of its own context in this regard, and their fans authenticate their performance with their adoration and devotion.

I argue that Gnawa Diffusion manifests the call of the Sidi Bilal for spiritual jihad. Traditional Gnawa music heals those who are possessed by jinn in a world full of pain. Gnawa Diffusion promotes maintenance of self-worth and memories of origins and deep history 
for those far from home. They reference memories of peace and reconciliation directly through text and music (Gnawa Diffusion 1997; 2004), and offer narratives of liberation from bondage. Gnawa lament Africa's torments and they travel the world doing so in various contexts with all shades of Africans (Kapchan 2007), as has Gnawa Diffusion. Gnawa Diffusion had the right to seek to heal themselves and the places they are from with their music by memorializing the struggles of people like themselves. Gnawa Diffusion's intentions come from a place of respect and healing which are authentically tagnawit, or "of Gnawa" (ibid. 2007: 22), and it is likely their music increased the global reputation of the Gnawa rather than cheapening sacred traditions. If we choose to, we can understand why Gnawa Diffusion's music should not be separately judged by each of the standards of its parceled roots, identities, histories, and influences. Rather, it should be authenticated by the quality of its attempt to perform a reconciliation of the harmful cleavages that birthed Gnawa Diffusion.

Acknowledgements: My thanks to David Font, Rob Simms, Amanda Di Battista, Ellen Sweeney, Yacine Addoun, William Gerber, Louise Wrazen, Meredith, Ken, and Alison McEvoy for their help. Any shortcomings in this paper are entirely my own. 


\section{References}

Baldassarre, Antonio. 2005. "The music of the Gnawa of Morocco: A journey with the other into the elsewhere." In Luisa Del Giudice and Nancy van Deusen eds., Performing Ecstasies: Music, dance, and ritual in the Mediterranean. Ottawa: The Institute of Mediaeval Music: 81-88.

Basu, Dipannita and Sidney Lemelle eds. 2006. The vinyl ain't final: Hip hop and the globalization of black popular culture. London: Pluto Press.

Beriss, David. 2004. Black skins, French voices: Caribbean ethnicity and activism in urban France. New Orleans. Boulder: Westview Press.

Buchanan, Donna. 2006. Performing democracy: Bulgarian music and musicians in transition. Chicago: University of Chicago Press.

Claisse, Pierre-Alain. 2003. Les Gnawa moracains de tradition loyaliste. Paris: L'Harmattan.

Corcoran, Patrick. 2007. The Cambridge introduction to francophone literature. New York: Cambridge University Press.

El Hamel, Chouki. 2008. "Constructing a diasporic identity: Tracing the origins of the Gnawa spiritual group in Morocco." In The Journal of African History 49 (02): 241-60.

Feld, Steven. 1984. "Communication, music, and speech about music." In Yearbook for Traditional Music 16: 1-18.

Helenon, Veronique. 2006. "Africa on their mind: Rap, blackness, and citizenship in France." In Dipannita Basu and Sidney Lemelle, The vinyl ain't final: Hip hop and the globalization of black popular culture. London: Pluto Press: 151-156.

Hoffman, Katherine E. 2008. We share walls: Language, land, and gender in Berber Morocco. Oxford: Blackwell Publishing.

Jankowsky, Richard C. 2007. "Music, spirit possession and the inbetween: Ethnomusicological inquiry and the challenge of trance." In Ethnomusicology Forum 16 (2): 185-208.

--. 2004. "The other people": Music, race, and rituals of possession in Tunisian stambeli. Ph.D. The University of Chicago.

Kapchan, Deborah. 2007. Traveling spirit masters: Moroccan Gnawa, trance, and music in the global market place. Middletown: Wesleyan University Press.

--. 2002. "Possessing Gnawa culture: Displaying sound, creating history in an unofficial museum." In Music \& Anthroplogy 7, http://www. fondazionelevi.org/ma/index/number7/kapchan/kap_00.htm, (accessed February 1, 2012). 
Kazak, Amin. 1996. "The Berber Tamazight Movement in Morocco and Algeria." In Fourth World Bulletin. Fall 1994/Winter 1995, (accessed January 5, 2012). http://www.amazighworld.org/history/ modernhistory/berber_movement_morocco_algeria.php.

Langlois, Tony. 1998. "The Gnawa of oujda: Music at the margins in Morocco." In The World of Music 40 (1): 135-56.

Mark, Andrew. 2011. "Divided Kingdom Mbira: Zimbabwean hip-hop in London." In Monique Desroches et al., Territoires musicaux mis en scène. Montréal: Les Presses de l'Université de Montréal : 399-414.

Meintjes, Louis. 1990. "Paul Simon's Graceland, South Africa, and the mediation of musical meaning." In, Ethnomusicology 34 (1): 37-73.

Osumare, Halifu. 2007. The Africanist aesthetic in global hip-hop: Power moves. New York: Palgrave MacMillon.

Paques, Viviana. 2005 [1954]. Les Bambara. Paris: L'Harmattan.

Sayad, Abdelmalek. 2004. The suffering of the immigrant. Cambridge: Polity Press.

Silverstein, Paul. 2004. Algeria in France: Transpolitics, Race, and Nation. Bloomington, Indiana: University Press.

Snow, David, al., 2007. "Framing the French riots: A comparative study of frame variation." In Social Forces, 86(2): 385-415.

Taylor, Timothy. 2007. Beyond exoticism: Western music and the world. Durham: Duke University Press.

Water Te, Aman. 2004. "Morocco: Musical inspiration in Essaouira." In New African: $72-73$.

Thomas, Dominic. 2007. Black France: Colonialism, immigration, and transnationalism. Bloomington: Indiana University Press.

Turino, Thomas. 2000. Nationalists, cosmopolitans, and popular music in Zimbabwe. Chicago: University of Chicago Press.

Wahab, Amar. 2005. "Consuming narratives: Questioning authority and the politics of representation in social science research." In George Dei and Gurpreet Johal, Critical Issues in Anti-Racist Research Methodologies. New York: Peter Lang Publishing: 29-52.

Waugh, Earle. 2005. Memory, music, and religion: Morocco's mystical chanters. South Carolina: University of South Carolina Press.

Wendt, Caroline. 1997. "North Africa: An introduction.” In The Garland Encyclopedia of Music Vol. 1: Africa, Ruth Stone. New York: Routledge: 532-47, (accessed March 31, 2012), http://glnd.alexanderstreet.com. ezproxy.library.yorku.ca/View/327162. 


\section{Autres references}

Addoun, Yacine Daddi. 2009. Email communication. York University, Toronto, January.

BBC. Country profile: Algeria. British Broadcasting Corporation, http://news. bbc.co.uk/2/hi/middle_east/country_profiles/790556.stm. (Accessed December 8, 2012).

Bowles, Paul. 1990. Gnawa music of Marrakesh: Night spirit masters. CD liner notes. Island Records.

Brown, Daniel. 2008. "Rap musician under legal fire for 'defamation.” Radio France International / Freemuse. http://www.freemuse.org/sw28748.asp. (Accessed February 1, 2012).

Chehat, Fayçal. 1998. "The Maghreb's roots lie in the South: Interview with Amazigh Kateb (Gnawa Diffusion)". Africultures, (13), http://www. africultures.com/php/index.php?nav $=$ article\& no $=5326$.

--. 1998. The Maghreb's roots lie in the South: interview with Amazigh Kateb (Gnawa Diffusion), Africultures 13.

Festival Gnaoua. 2012. http://www.festival-gnaoua.net/en. (Accessed February 20, 2012).

Gnawa Diffusion. 2009. Homepage, bios. http://www.gnawa-diffusion.com/ accueil.htm. (Accessed February 1, 2009-webpage/homepage for band no longer exists-there is a Facebook page now, with scant details about the reunion tour and album).

--, Fucking Cowboys. 2007. CD and DVD. Uncivilized World. http://www. gnawa-diffusion.com/2007. (Accessed January 17, 2009-webpage/ homepage for band no longer exists).

--, Souk System. Warner, 2004.

--, Live DZ. CD. Next Music, 2001.

_-, Bab El Oued Kingston. CD. 7 Colors Music, 1999.

--, Algeria. CD. G.D.O. Records, 1997.

--, Legitime Difference. CD. Independent, 1993.

Gouri, Yassine. 2012. Turn Again Music. http://en.turnagainmusic.com/ artiste-26-gnawa-diffusion.html. (Accessed November 28, 2012)

Marsaud, Olivi. 2004. "Amazigh Kateb, l'homme libre: Rencontre avec le chanteur de Gnawa Diffusion”, in Afrik.com, (Accessed January 2012), http://www.afrik.com/article7602.html.

Mutasa, Alice. 2010. "Interview with Amazigh Kateb: at the Festival Gnaoua et Musiques du Monde." In Places and Seasons. Essaouira, Morocco. (Accessed November 29, 2012) http://www.placesandseasons. com/2010/07/interview-with-amazigh-kateb/ 
Poggioli, Sylvia. 2005. "French rap musicians blamed for violence." National Public Radio. (Accessed February 10, 2012), http://www.npr.org/ templates/story/story.php?storyId=5052650.

Pontecorvo, Gillo. 1966. The Battle of Algiers. DVD. The Criterion Collection. Saidani, Aziz ben. 2003. "Amazigh Kateb Yacine discusses Maghreb blues and Ghanawa music-a diffusion of Berber, Arabic genres." Translated by Elie Chalala. Zawayya magazine. (Accessed February 10, 2012), http://www. aljadid.com/content/amazigh-kateb-yassin-discusses-maghreb-blues-andghanawa-music\%E2\%80\%93-diffusion-berber-arabic-genr.

Schofield, Hugh. 2005. French rappers' prophecies come true. British Broadcasting Corporation. (Accessed February 10, 2012), http://news.bbc. co.uk/2/hi/europe/4440422.stm.

Schuler, Philip. "Morocco" In Grove Music Online. Oxford Music Online, (Accessed March 31, 2012),

http://www.oxfordmusiconline.com.ezproxy.library.yorku.ca/subscriber/ article/grove/music/19156.

Smati, Samar. 1999. "Insolence et pertinence du'un Kateb.” In L'actu. de PlaNet DZ. (Accessed March 10, 2012) http://www.planet-dz.com/ ACTU/2000/juillet/interview_amazigh.htm.

Zergane, Monia and Guillaume Billard. 2006. "Interview avec Amazigh Kateb, Gnawa Diffusion Amaz L’Africain.” In Evene.fr. (Accessed March 3), $2012 \mathrm{http}: / /$ translate.google.com/translate?prev $=\mathrm{hp} \& \mathrm{hl}=\mathrm{en} \& \mathrm{js}=\mathrm{n} \&$ $\mathrm{u}=\mathrm{http} \% 3 \mathrm{~A} \% 2 \mathrm{~F} \% 2 \mathrm{Fwww}$.evene.fr\%2Fmusique\%2Factualite\%2Finterv iew-de-amazigh-kateb-gnawa-diffusion-551.php\&sl=fr\&tl=en. 